\title{
Article
}

\section{The Pennsylvania Longitudinal Study of Parents and Children (PALSPAC) Twin Registry}

\author{
Amanda M. Ramos ${ }^{1}$, Tong Chen ${ }^{1}$, Peter K. Hatemi ${ }^{2}$, H. Harrington Cleveland ${ }^{3}$ and Jenae M. Neiderhiser ${ }^{1}$ \\ ${ }^{1}$ Department of Psychology, The Pennsylvania State University, University Park, PA, USA, ${ }^{2}$ Department of Political Science, The Pennsylvania State University, \\ University Park, PA, USA and ${ }^{3}$ Human Development and Family Studies, The Pennsylvania State University, University Park, PA, USA
}

\begin{abstract}
The Pennsylvania Longitudinal Study of Parents and Children Twin Registry was developed to capture a representative sample of multiple births and their parents in the state of Pennsylvania. The registry has two main efforts. The first began in 2012 through recruitment of adolescents in Pennsylvania schools. The second effort began in January 2019 in partnership with the Pennsylvania Department of Health to capture the birth cohort of twins born from 2007 to 2017. Study recruitment, sample demographics, focus and measures are provided, as well as future directions.
\end{abstract}

Keywords: Environment; genetic; health; rural and urban; Twin

(Received 29 June 2019; accepted 11 July 2019; First Published online 31 October 2019)

The purpose of the Pennsylvania Longitudinal Study of Parents and Children (PALSPAC) Twin Registry is to establish a population-based twin sample of multiple birth children born in Pennsylvania (PA) to address central questions of development related to mental and physical health. We are especially interested in understanding and describing the development of positive and negative health outcomes and prosocial traits through the life course, accounting for the interplay of genes and environments.

The population of PA is unique in a number of important ways that make establishing a population-based longitudinal twin registry, beginning from infancy and following children through adulthood, especially important. First, the proportion of individuals living rurally in PA is among the highest in states with large populations. In fact, due to its combination of large total population and a high percentage of rural residents (over 20\%), PA has one of the largest rural populations of the USA (U.S. Census Bureau, 2012; U.S. Department of Agriculture, 2018). Thus, a PA-based twin registry will have substantial numbers of urban and rural twin-pairs - facilitating examination of life influences on developmental processes across these critically different environments. This is especially important as there has been very little genetically informed research on rural populations to date (e.g., Connolly et al., 2017; Davis et al., 2017; Dick et al., 2009; Legrand et al., 2008). Second, PA's level of out-migration is among the lowest in the USA, with approximately $72 \%$ of the residents being born in PA (U.S. Census Bureau, 2010, 2017). Simply put, people who are born in PA tend to stay here. This stability in the population throughout the state provides an important opportunity

Author for correspondence: Jenae M. Neiderhiser, Email: jmn101@psu.edu and Amanda M. Ramos, Email: amr438@psu.edu

Cite this article: Ramos AM, Chen T, Hatemi PK, Cleveland HH, and Neiderhiser JM. (2019) The Pennsylvania Longitudinal Study of Parents and Children (PALSPAC) Twin Registry. Twin Research and Human Genetics 22: 765-768, https://doi.org/10.1017/ thg.2019.98 to follow research participants across the lifespan. In the context of behavioral genetic research, this population stability provides an especially promising opportunity to examine the influences of childhood experiences on later outcomes, with the ability to estimate relative genetic and environmental influences. Building a population-based registry in PA will facilitate research addressing how specific aspects of context, such as being in neighborhoods with low access to healthy food options, can affect the development of health problems, such as obesity.

\section{Twin Family Recruitment}

The PALSPAC Twin Registry has used two recruitment efforts with the goal of obtaining population representative samples of adolescent and child twins. The first recruitment effort was used from 2012 to 2014 and was focused on recruiting adolescent twins. The second recruitment effort is currently ongoing in partnership with the PA Department of Health (PA DOH) to recruit families with young children born in 2016-2017 (begun January 2019). During the adolescent recruitment effort, families were recruited via PA junior high/middle and high schools. We identified school districts throughout the state using a two-step approach. First, we systematically categorized schools based on population density, and then we randomly selected schools to contact within the different categories. Once the schools were identified, they were contacted by a research assistant who provided information about the registry and sought permission to provide study recruitment materials to the families of twins enrolled at that school. Schools that agreed provided the number of twin-pairs enrolled in the school, and research staff sent the recruitment materials to the school, to be sent home with the twins (recruitment letter, consent form and enrollment form). Families who were interested in participating could do so by returning the paper enrollment form or by enrolling online. Once parents completed the enrollment form, the parents and multiples 
were added into the registry. During this recruitment, we collaborated with individuals at other PA universities in order to increase our recruitment. One such successful collaboration was with the Pittsburgh Registry of Infant Multiples (Strassberg et al., 2002), which recruited families of twins from birth records at a Pittsburgh hospital. In addition, our online registry website and enrollment form enable families to find us via web searches or other means and to complete the enrollment form at any time. As time has passed, many of our twins are no longer minors, so we have modified enrollment to allow twins over the age of 18 to be a part of the registry. This recruitment approach has yielded 450 families.

The current recruitment began in 2019 in collaboration with the PA DOH. The PA DOH identified all multiple births that had occurred in PA between August 2007 and August 2017. Names and addresses of all of the mothers of twins or other multiples were extracted from these birth records. The total number of multiple births between 2007 and 2017 was approximately 50,000. We began our recruitment by selecting a random sample of 1000 families with multiple births between 2016 and 2017. Parents of twins were sent a letter about the PALSPAC: Children's study along with the PALSPAC twin registry. We request that they complete the brief survey and registry enrollment via mail or web. Parents are sent $\$ 10$ for completing the survey. The response rate from our first mailing was $13 \%$, with $88 \%$ of those responding agreeing to become part of the PALSPAC Twin Registry. We have completed the first mailing and are in the process of attempting the two follow-up contacts permitted by our agreement with the PA $\mathrm{DOH}$. For families for whom we can find a phone number or email address, we will use an alternative strategy of contact for our second and/or third contact attempt. Each subsequent contact occurs approximately a month after a prior attempt. Our second recruitment effort (ongoing) has currently enrolled 115 families. Once we have completed our pilot recruitment of 1000 families of multiples, we will evaluate our success in recruiting a sample representative of PA families (e.g., urbanicity, race and poverty). Given our early results, we anticipate continued success and will expand our registry to include more birth years. We are currently not collecting DNA for either effort.

\section{Zygosity Determination}

Zygosity is determined through parent reporting of the similarity of the twins using eight items. The measure includes how similar they are ('as alike as two peas in a pod' or 'of a normal family likeness'), the probability of the twins being fraternal or identical and global similarity ratings (i.e., the extent that they cannot be told apart: family, teachers and strangers; Nichols \& Bilbro, 1966).

\section{Data Collection Projects}

The PA Twins Adolescent study was conducted from 2016 to 2017 using twins recruited from schools and collaborations with researchers at the University of Pittsburgh. The main purpose of this study was to investigate genetic and environmental influences on adolescents' and young adults' family and peer relationships and socioemotional adjustment outcomes (e.g., substance use, depression, problem behavior and wellbeing). Twins between the ages of 9 and 23 who were fluent in English were recruited into this study. Families were sent recruitment letters via mail or email and completed the survey via mail or web. Parents and twins over 18 provided consent and twins under 18 years of age provided assent after parental consent was obtained. Measures were focused on psychosocial development, substance use and related
Table 1. Demographic information for our enrolled families

\begin{tabular}{|c|c|c|}
\hline & Effort $1(n=450)$ & Effort $2(n=115)$ \\
\hline \multicolumn{3}{|l|}{ Parent } \\
\hline Mean age at enrollment (SD) & $42.67(7.75)$ & $34.23(4.65)$ \\
\hline Range & $18-88$ & $21-48$ \\
\hline \multicolumn{3}{|l|}{ Ethnicity (\%) } \\
\hline Caucasian & 81.2 & 82.6 \\
\hline African American & 3.6 & 6.1 \\
\hline Hispanic & 2.5 & 6.1 \\
\hline Asian & 1.1 & 1.7 \\
\hline Other ${ }^{\mathrm{a}}$ & 11.7 & 3.5 \\
\hline \multicolumn{3}{|l|}{ Education level (\%) } \\
\hline Less than high-school degree & 1.8 & 6.1 \\
\hline High-school degree or GED & 11.2 & 8.7 \\
\hline Business or trade school & - & 3.5 \\
\hline Some college & 16.8 & 9.6 \\
\hline Associate's degree & - & 7.0 \\
\hline 4-year college degree or more & 58.5 & 62.6 \\
\hline Married (\%) & 73.5 & 76.5 \\
\hline Mean household income $(S D)^{\mathrm{b}}$ & $3.96(1.3)$ & $3.91(1.24)$ \\
\hline $\begin{array}{l}\text { Mean number of children } \\
\text { in household }(S D)\end{array}$ & $2.73(0.86)$ & $3.21(1.24)$ \\
\hline $\begin{array}{l}\text { Mean number of adults } \\
\text { in household }(S D)\end{array}$ & $2.28(0.91)$ & $2.09(0.63)$ \\
\hline \multicolumn{3}{|l|}{ Twins } \\
\hline Gender ( $\%$ male) & 44.1 & 52.6 \\
\hline \multicolumn{3}{|l|}{ Zygosity (\%) } \\
\hline MZ & 35.7 & 27.0 \\
\hline $\mathrm{DZ}$ & 55.2 & 67.8 \\
\hline Don't know & 9.2 & 5.3 \\
\hline Mean age at enrollment (SD) & $12.21(6.52)$ & $2.82(0.39)$ \\
\hline Range & $0-64$ & $2-3$ \\
\hline
\end{tabular}

Note: Parent information is for mothers. $M Z=$ monozygotic, $D Z=$ dizygotic, GED = General Educational Development.

aOther: multiracial, don't know.

$\mathrm{b}(1)$ Less than $\$ 20 \mathrm{k},(2)$ more than $\$ 20 \mathrm{k}$, less than $\$ 35 \mathrm{k}$, (3) more than $\$ 35 \mathrm{k}$, less than $\$ 60 \mathrm{k}$, (4) more than $\$ 60 \mathrm{k}$, less than $\$ 100 \mathrm{k}$, (5) more than $\$ 100 \mathrm{k}$, less than $\$ 150 \mathrm{k}$ and $(6)$ more than $\$ 150 \mathrm{k}$.

behaviors, interpersonal relationships, physical health and pubertal development (Table 2). Of the 327 families eligible to participate, $65 \%$ could be contacted $(n=214)$, and of those, $78 \%$ of parents completed the survey for both twins $(n=167)$ and $50 \%$ of twins completed surveys ( $n=91$ complete pairs). Demographic characteristics of the participating twin families are consistent with the enrolled families from the first recruitment effort (see Table 1).

With the PA DOH recruitment, families were contacted to complete a survey with the purpose of understanding genetic and environmental influences on young children's health. Data collection is ongoing; measures are listed in Table 2.

\section{Demographics for Families with Multiple Births}

Using data provided from the PA DOH, we examined the demographic characteristics of multiple births in PA to provide some 
Table 2. Description of measures in the PA Twins Adolescent Study and PALSPAC Study

\begin{tabular}{|c|c|}
\hline Construct & Measure \\
\hline \multicolumn{2}{|c|}{ PA Twins Adolescent Study } \\
\hline \multicolumn{2}{|l|}{ Physical development } \\
\hline & $\begin{array}{l}\text { Pubertal Development Scale (Petersen et al., } \\
\text { 1988) }\end{array}$ \\
\hline \multicolumn{2}{|c|}{ Parent/child characteristics } \\
\hline \multirow[t]{4}{*}{ Anxiety } & $\begin{array}{l}\text { Penn State Worry Questionnaire (Meyer et al., } \\
\text { 1990) }\end{array}$ \\
\hline & Anxiety Discussion Questionnaire \\
\hline & $\begin{array}{l}\text { Generalized Anxiety Disorder Questionnaire } \\
\text { (Newman et al., 2002) }\end{array}$ \\
\hline & $\begin{array}{l}\text { Child Anxiety-Related Disorders (DeSousa et al., } \\
\text { 2014) }\end{array}$ \\
\hline Depression & $\begin{array}{l}\text { Center for Epidemiologic Studies Depression } \\
\text { Scale (Radloff, 1977) }\end{array}$ \\
\hline \multirow[t]{2}{*}{ Personality } & $\begin{array}{l}\text { Big } 5 \text { Personality Measure (John \& Srivastava, } \\
\text { 1999) }\end{array}$ \\
\hline & $\begin{array}{l}\text { Ten-Item Personality Inventory (Ehrhart } \\
\text { et al., 2009) }\end{array}$ \\
\hline \multicolumn{2}{|l|}{ Adolescent behavior } \\
\hline Positive wellbeing & $\begin{array}{l}\text { Scales of Psychological Wellbeing (van } \\
\text { Dierendonck, 2004) }\end{array}$ \\
\hline Helpfulness & Helpfulness (Eberly \& Montemayor, 1998) \\
\hline \multirow[t]{2}{*}{ Antisocial behaviors } & Zil (Zil, 1987) \\
\hline & Social Desirability Scale (Ballard, 1992) \\
\hline Resilience & Grit Scale (Duckworth \& Quinn, 2009) \\
\hline Substance use & Add health \\
\hline \multicolumn{2}{|l|}{ Family relationships } \\
\hline \multirow[t]{2}{*}{ Marital } & Behavior Affect Rating Scale (Melby et al., 1995) \\
\hline & $\begin{array}{l}\text { Children's Perceptions of Interparental Conflict } \\
\text { (short form; Grych et al., 1992) }\end{array}$ \\
\hline \multirow[t]{2}{*}{ Parent-child } & $\begin{array}{l}\text { Parental Environment Questionnaire } \\
\text { (Elkins et al., 1997) }\end{array}$ \\
\hline & $\begin{array}{l}\text { Parent-Child Relationship Scale (Hetherington \& } \\
\text { Clingempeel, 1992) }\end{array}$ \\
\hline \multirow[t]{3}{*}{ Peer and sibling } & $\begin{array}{l}\text { Sibling and Interaction Task Report } \\
\text { (Hetherington \& Clingempeel, 1992) }\end{array}$ \\
\hline & $\begin{array}{l}\text { Friendship Qualities Scale (Bukowski } \\
\text { et al., 1994) }\end{array}$ \\
\hline & $\begin{array}{l}\text { Peer Victimization Scale (Mynard \& Joseph, } \\
\text { 2000) }\end{array}$ \\
\hline \multicolumn{2}{|l|}{ Internet and media use } \\
\hline & $\begin{array}{l}\text { Internet and Media Consumption } \\
\text { (Noll et al., 2013) }\end{array}$ \\
\hline & $\begin{array}{l}\text { Mobile Phone Involvement Questionnaire } \\
\text { (Walsh et al., 2010) }\end{array}$ \\
\hline \multicolumn{2}{|l|}{ Political issues } \\
\hline & Attitudes (Wilson \& Patterson, 1968) \\
\hline \multicolumn{2}{|c|}{ PALSPAC: Children's Study } \\
\hline Demographics & Education, Income and Twin Care \\
\hline Prenatal & Smoking and Complications \\
\hline
\end{tabular}

Table 2. (Continued)

\begin{tabular}{ll}
\hline Construct & Measure \\
\hline Breastfeeding & $\begin{array}{l}\text { Breastfeeding Behaviors (adapted from NIH } \\
\text { toolbox) }\end{array}$ \\
\hline Health & Child Health (Fagot \& Pears, 1994) \\
\hline Sleep behaviors & $\begin{array}{l}\text { Sleep Habits Questionnaire (Goodlin-Jones } \\
\text { et al., 2008) }\end{array}$ \\
\hline $\begin{array}{l}\text { Tayside Children's Sleep Questionnaire } \\
\text { (McGreavey et al., 2005) }\end{array}$ \\
\hline Eating behaviors & $\begin{array}{l}\text { Child Eating Behavior Questionnaire } \\
\text { (Wardle et al., 2001) }\end{array}$ \\
\hline
\end{tabular}

context for our anticipated recruitment. As noted earlier, PA has a large population, with 700,391 births through the state from 2013 to 2017. During that time, 20,012 of those births were multiple births (2.9\%). Using the Penn State University (PSU) Office of Management and Budget categorizations for urban and rural, we determined that approximately $12 \%$ of those multiple births were in rural areas. As expected, race and ethnicity distributions for multiple births are consistent with statewide distributions, with $72 \%$ Caucasian, 16\% Black, 9\% other (primarily Asian) and $3 \%$ unknown. Six percent of families with a multiple birth between 2013 and 2017 identify as Hispanic. As can be seen in Table 2, these demographics are consistent with the subset that has been recruited to date.

\section{Data Management, Registry Access and Collaboration}

The PALSPAC Twin Registry is maintained at PSU. During the recruitment phase, we ask families whether they are willing to share their information to be recruited for additional studies and investigators outside of PSU; therefore, our registry and access to the current data collection are open to other investigators, and we welcome future collaborations. We have successfully completed one such collaboration with Dr Bucan at the University of Pennsylvania who recruited twins from our first recruitment effort to participate in an actigraphy study (Gehrman et al., 2019).

\section{Future Directions}

Although the PALSPAC Twin Registry is at the beginning of its enrollment, its potential as a resource for understanding rural versus urban influences is unique. Many of the twins enrolled in the first recruitment effort are nearing early adulthood ( $40 \%$ are 16 or older), allowing researchers to address important questions surrounding how early-life environments influence the development of health lifestyles into adulthood. Our second recruitment effort will continue to recruit families with twin children in early childhood and middle childhood. This will allow us to follow infants, children and preadolescents longitudinally. We hope to collaborate with other researchers interested in assessing these families across time to explicate the development of positive and negative health trajectories through the life course, accounting for genes and environment and their interplay. We are especially eager to incorporate the role of neighborhood context, including a nuanced assessment of rural and urban neighborhoods, and their distinct influences on the mental and physical health of children and their families. 
Acknowledgements. We would like to thank all the families participating in the registry as well as research staff who have helped to manage and recruit families into the registry.

Financial support. This work was supported by institutional grants from PSU's Social Science Research Institute, and the Center for Human and Evolutionary Diversity, and from internal research funds of Drs Neiderhiser and Cleveland.

\section{Conflict of interest. None.}

Ethical standards. The authors assert that all procedures contributing to this work comply with the ethical standards of the relevant national and institutional committees on human experimentation and with the Helsinki Declaration of 1975, as revised in 2008 .

\section{References}

Ballard, R. (1992). Short forms of the Marlowe-Crowne Social Desirability Scale. Psychological Reports, 71, 1155-1160.

Bukowski, W. M., Hoza, B., \& Boivin, M. (1994). Measuring friendship quality during pre- and early adolescence: The development and psychometric properties of the Friendship Qualities Scale. Journal of Social and Personal Relationships, 11, 471-484.

Connolly, E. J., Lewis, R. H., \& Boisvert, D. L. (2017). The effect of socioeconomic status on delinquency across urban and rural contexts: Using a genetically informed design to identify environmental risk. Criminal Justice Review, 42, 237-253.

Davis, C. N., Natta, S. S., \& Slutske, W. S. (2017). Moderation of genetic influences on alcohol involvement by rural residency among adolescents: Results from the 1962 National Merit Twin Study. Behavior Genetics, 47, 587-595.

DeSousa, D. A., Zibetti, M. R., Trentini, C. M., Koller, S. H., Manfro, G. G., \& Salum, G. A. (2014). Screen for child anxiety related emotional disorders: Are subscale scores reliable? A bifactor model analysis. Journal of Anxiety Disorders, 28, 966-970.

Dick, D. M., Bernard, M., Aliev, F., Viken, R., Pulkkinen, L., Kaprio, J., \& Rose, R. J. (2009). The role of socioregional factors in moderating genetic influences on early adolescent behavior problems and alcohol use. Alcoholism, Clinical and Experimental Research, 33, 1739-1748.

Duckworth, A. L., \& Quinn, P. D. (2009). Development and validation of the Short Grit Scale (GRIT-S). Journal of Personality Assessment, 91, 166-174.

Eberly, M. B., \& Montemayor, R. (1998). Doing good deeds: An examination of adolescent prosocial behavior in the context of parent-adolescent relationships. Journal of Adolescent Research, 13, 403-432.

Ehrhart, M. G., Ehrhart, K. H., Roesch, S. C., Chung-Herrera, B. G., Nadler, K., \& Bradshaw, K. (2009). Testing the latent factor structure and construct validity of the Ten-Item Personality Inventory. Personality and Individual Differences, 47, 900-905.

Elkins, I. J., McGue, M., \& Iacono, W. G. (1997). Genetic and environmental influences on parent-son relationships: Evidence for increasing genetic influence during adolescence. Developmental Psychology, 33, 351-363.

Fagot, B. I., \& Pears, K. C. (1994). Developmental History. Unpublished OSLC instrument. (Available from OSLC, 10 Shelton- McMurphey Blvd, Eugene, OR 97401.)

Gehrman, P. R., Ghorai, A., Goodman, M., McCluskey, R., Barilla, H., Almasy, L., ... Bucan, M. (2019). Twin-based heritability of actimetry traits. Genes, Brain and Behavior, 18, e12569.

Goodlin-Jones, B. L., Sitnick, S. L., Tang, K., Liu, J., \& Anders, T. F. (2008). The Children's Sleep Habits Questionnaire in toddlers and preschool children. Journal of Developmental and Behavioral Pediatrics, 29, 82-88.

Grych, J. H., Seid, M., \& Fincham, F. D. (1992). Assessing marital conflict from the child's perspective: The children's perception of Interparental Conflict Scale. Child Development, 63, 558-572.
Hetherington, E. M., \& Clingempeel, W. G. (1992). Coping with marital transitions: A family systems perspective. Monographs of the Society for Research in Child Development, 57, i-238.

John, O P., \& Srivastava, S. (1999). The Big Five trait taxonomy: History, measurement, and theoretical perspectives. In L. A. Pervin \& O. P. John (Eds.), Handbook of personality: Theory and research (2nd ed., pp. 102-138). New York, NY: The Guilford Press.

Legrand, L. N., Keyes, M., McGue, M., Iacono, W. G., \& Krueger, R. F. (2008). Rural environments reduce the genetic influence on adolescent substance use and rule-breaking behavior. Psychological Medicine, 38, 1341-1350.

McGreavey, J. A., Donnan, P. T., Pagliari, H. C., \& Sullivan, F. M. (2005). The Tayside Children's Sleep Questionnaire: A simple tool to evaluate sleep problems in young children. Child: Care, Health and Development, 31, 539-544.

Melby, J. N., Conger, R. D., Ge, X., \& Warner, T. D. (1995). The use of structural equation modeling in assessing the quality of marital observations. Journal of Family Psychology, 9, 280-293.

Meyer, T. J., Miller, M. L., Metzger, R. L., \& Borkovec, T. D. (1990). Development and validation of the Penn State Worry Questionnaire. Behaviour Research and Therapy, 28, 487-495.

Mynard, H., \& Joseph, S. (2000). Development of the multidimensional peervictimization scale. Aggressive Behavior, 26, 169-178.

Newman, M. G., Zuellig, A. R., Kachin, K. E., Constantino, M. J., Przeworski, A., Erickson, T., \& Cashman-McGrath, L. (2002). Preliminary reliability and validity of the Generalized Anxiety Disorder Questionnaire-IV: A revised self-report diagnostic measure of generalized anxiety disorder. Behavior Therapy, 33, 215-233.

Nichols, R. C., \& Bilbro, W. C. (1966). The diagnosis of twin zygosity. Acta Genetica et Statistica Medica, 16, 265-275.

Noll, J. G., Shenk, C. E., Barnes, J. E., \& Haralson, K. J. (2013). Association of maltreatment with high-risk internet behaviors and offline encounters. Pediatrics, 131, e510-e517.

Petersen, A. C., Crockett, L., Richards, M., \& Boxer, A. (1988). A self-report measure of pubertal status: Reliability, validity, and initial norms. Journal of Youth and Adolescence, 17, 117-133.

Radloff, L. S. (1977). The CES-D Scale: A Self-Report Depression Scale for research in the general population. Applied Psychological Measurement, 1, 385-401.

Strassberg, M., Peters, K., Marazita, M., Ganger, J., Watt-Morse, M., Murrelle, L., Vanyukov, M. (2002). Pittsburgh Registry of Infant Multiplets (PRIM). Twin Research and Human Genetics, 5, 499-501.

U.S. Census Bureau. (2010). Migration. Retrieved from https://www.census. gov/population/www/cen2000/censusatlas/

U.S. Census Bureau. (2012). Growth in urban population outpaces rest of nation. Retrieved from https://www.census.gov/newsroom/releases/archives/ 2010_census/cb12-50.html

U.S. Census Bureau. (2017). State of residence by state of birth: 2017. Retrieved from https:/www.census.gov/topics/population/migration/guidance/stateof-residence-by-place-of-birth-flows-acs-prcs.html

U.S. Department of Agriculture. (2018, November). Rural American at a Glance 2018 Edition. Retrieved from https://www.ers.usda.gov/publications/pubdetails/?pubid $=90555$

van Dierendonck, D. (2004). The construct validity of Ryffs Scales of Psychological Well-being and its extension with spiritual well-being. Personality and Individual Differences, 36, 629-643.

Walsh, S. P., White, K. M., \& Young, R. M. (2010). Needing to connect: The effect of self and others on young people's involvement with their mobile phones. Australian Journal of Psychology, 62, 194-203.

Wardle, J., Guthrie, C. A., Sanderson, S., \& Rapoport, L. (2001). Development of the Children's Eating Behaviour Questionnaire. Journal of Child Psychology and Psychiatry, and Allied Disciplines, 42, 963-970.

Wilson, G. D., \& Patterson, J. R. (1968). A new measure of conservatism. The British Journal of Social and Clinical Psychology, 7, 264-269.

Zill, N. (1987). Behavior, achievement, and health problems among children in stepfamilies: Findings from a national survey of child health. Washington, DC: Child Trends. 